\title{
Latin American and Caribbean earthquakes in the GEM's Earthquake Consequences Database (GEMECD)
}

\author{
Omar-Darío Cardona ${ }^{1} \cdot$ Mario Ordaz $^{2}$ - Mario A. Salgado-Gálvez ${ }^{3}$. \\ Alex H. Barbat ${ }^{3} \cdot$ Martha L. Carreño $^{4}$
}

Received: 15 March 2017/ Accepted: 17 October 2017

(C) Springer Science+Business Media B.V., part of Springer Nature 2017

\begin{abstract}
Among the activities developed under the framework of the Global Earthquake Model, the development of a global consequences database was included. This was defined with the objective of serving as public repository of damages and losses, occurred on different types of elements because of a selected list of earthquakes with epicentres at varying locations around the globe, but also to be used as a benchmark for the development of vulnerability models that capture specific characteristics of the building typologies in each country. The online earthquakes consequences' database has information on 71 events where 16 of them occurred in the Latin America and the Caribbean Region. A complete and comprehensive review and data gathering process were developed for these selected earthquakes accounting for different aspects and dimensions that were considered of interest, besides the physical damage, such as casualties, socio-economic implications, damages and disruptions in critical facilities and infrastructures, together with the occurrence of secondary events triggered by the ground shaking such as landslides and tsunamis.
\end{abstract}

Mario A. Salgado-Gálvez
mario.sal.gal@gmail.com
Omar-Darío Cardona
odcardonaa@unal.edu.co
Mario Ordaz
mordazs@iingen.unam.mx

Alex H. Barbat

alex.barbat@upc.edu

Martha L. Carreño

liliana@cimne.upc.edu

1 Instituto de Estudios Ambientales (IDEA), Universidad Nacional de Colombia Sede Manizales, Manizales, Colombia

2 Instituto de Ingeniería, Universidad Nacional Autónoma de México, Mexico City, Mexico

3 Centre Internacional de Mètodes Numèrics en Enginyeria (CIMNE), Universitat Politècnica de Catalunya, Barcelona, Spain

4 Centre Internacional de Mètodes Numèrics en Enginyeria (CIMNE), Barcelona, Spain 
When possible, the damage and casualties were geo-located using a standardized approach and included in the database. The contributions of the Latin America and Caribbean Region to the database were at the same time a challenge and an opportunity to collect, review, put together and standardize, up to a certain point, damage data of previous earthquakes additionally of being a step forward in the field of open data.

Keywords Earthquake consequences · Damage surveys · Lifelines · Earthquake casualties $\cdot$ Loss databases

\section{Introduction}

The documentation of the effects and consequences caused by events with natural and anthropogenic origin, together with the data gathering process to account for the effects in different relevant dimensions, (i.e. losses, casualties, displaced people), provides valuable information in the light of identifying risk, the latter being the first component of a comprehensive disaster risk management (DRM) strategy (Cardona 2009). Several disaster databases exist nowadays such as DesInventar and EM-DAT, the first one managed by the United Nations Office for Disaster Risk Reduction (UNISDR) and the Osso Corporation, whereas the second one by the Centre for Research on the Epidemiology of Disasters.

Although these disaster databases, among others, have overall and round figures about the consequences caused by events with geological origin, in which of course earthquakes are included, the availability of detailed data about effects and consequences inflicted by earthquakes and accounting for other dimensions different than the physical one (i.e. direct damages) are limited.

Among the components of the Global Earthquake Model (GEM), the development of a database with information about the consequences of earthquakes, considering a worldwide approach and with the objective of making available a public earthquake consequences database that served also as a benchmarking tool for analytical loss models, was completed (So 2014). The database was denoted as the Global Earthquake Model Earthquake Consequences Database (hereinafter GEMECD).

The reported information was included in the GEMECD considering different resolution levels, ranging from coarse-grain levels (denoted as Tier 0) up to a building by building/component by component resolution level (denoted as Tier 4). Intuitively, one may wrongly assume that information to populate the information using the Tier 4 level is only available for the most recent events in the region but surprisingly, even events that have occurred almost 50 years ago have detailed studies that allowed covering up to that resolution level.

Due to the large geographical scope of this project, ten different international partners contributed in the development of the GEMECD and among them, in the Latin America and the Caribbean (LAC) Region, ERN-AL Consortium (CIMNE, ERN and Ingeniar Ltda., among others) was in charge of populating the consequences database with data on 16 events which occurred between 1967 and 2010. Figure 1 shows the epicentre of these events.

Since some of these earthquakes have had consequences in dimensions different than building damages, such as casualties, socio-economic effects, secondary effects, damages in critical facilities and infrastructure (including lifelines) and damages on heritage sites, when possible, data about those aspects were also included in the data associated with each event. 


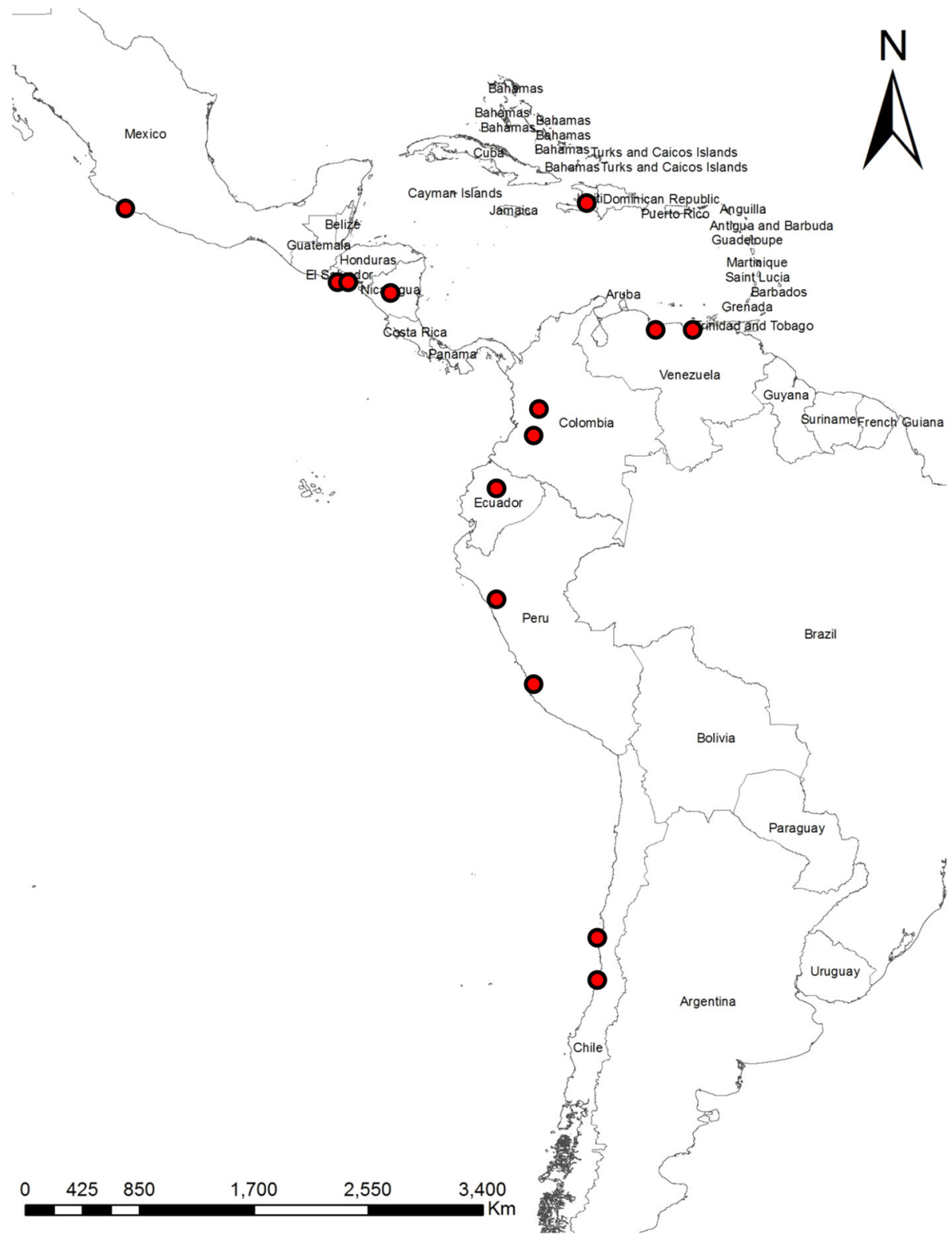

Fig. 1 Epicentres of the LAC earthquakes included in the GEMECD

With the aim of making the database a useful tool for benchmarking purposes related to the development and use of analytical loss models such as CAPRA Team RC+ (ERN and Ingeniar Ltda 2014) or openquake (Pagani et al. 2014), shakemaps for the chosen events were reviewed and updated by the USGS (García et al. 2012) with the objective of better correlating the hazard intensities with the reported damages and losses. Additionally, as an effort to make all information included in the database more transparent and 
understandable, a common taxonomy for the buildings was used, following the specifications and guidelines that were developed in parallel in separate GEM activities.

To guarantee the consistency in the information that feeds the database, and to display it in a standardized way, a guideline for the data gathering and arrangement processes was developed highlighting which aspects were to be captured and also how those needed to be included. Without doubts it was a challenging task since the way in which data from postevent surveys were available varied from event to event and also because many of the considered events in the LAC Region occurred and were documented before the widespread use of geographical information systems (GIS). Because of that, the digitalization of different kinds of data like, for example, hard copies of damage maps, besides the geolocation of considerable number of printed pictures, was required. For the completion of this activity, the contribution and collaboration of local experts and institutions was critical.

This paper presents a summary of the events included for LAC in the database highlighting, in each case, the most relevant aspects associated with each of them. For more information about specific details of the GEMECD approach, its structure and accessibility, the reader is suggested to read So (2014), which provides a complete documentation of those aspects.

\section{Latin America earthquakes included in the GEMECD}

It is well known that at least 29 countries in the LAC Region are located in seismic hazardprone areas (Salgado-Gálvez 2016). This fact, together with high levels of vulnerability in different of its dimensions (i.e. social, physical, economic, environmental), has led to important damages and losses after the occurrence of earthquakes in the region. Although those that have occurred in the vicinity of densely populated urban areas have associated large amounts of casualties and building damages and losses, other that have occurred at more distant locations from these sites have, in different cases, caused damages in other kind of infrastructure such as transportation and oil networks.

Table 1 shows a summary of the events in terms of country, nearest known location, date and also the specific dimensions that were covered. In all cases, at least the one that has to do with the damage of buildings (regardless if they are public or privately owned) is accounted for. Although in all the cases at least an order of magnitude about the casualties is available, for those events on which said dimension is included in Table 1 detailed information about it was included, such as the geospatial distribution and causes, when available.

A summary of the data that could be gathered for each event is included next, together with the list of references from where the available information was gathered.

\subsection{Caracas, Venezuela, 1967}

This event corresponds to the oldest included in the database which has occurred in the LAC Region. Its relevance in the earthquake engineering field is widely acknowledged, and it provided, at least within the region, material proofs of the importance of assessing the dynamic soil response and in considering that particular aspect in the design and construction of infrastructure. 


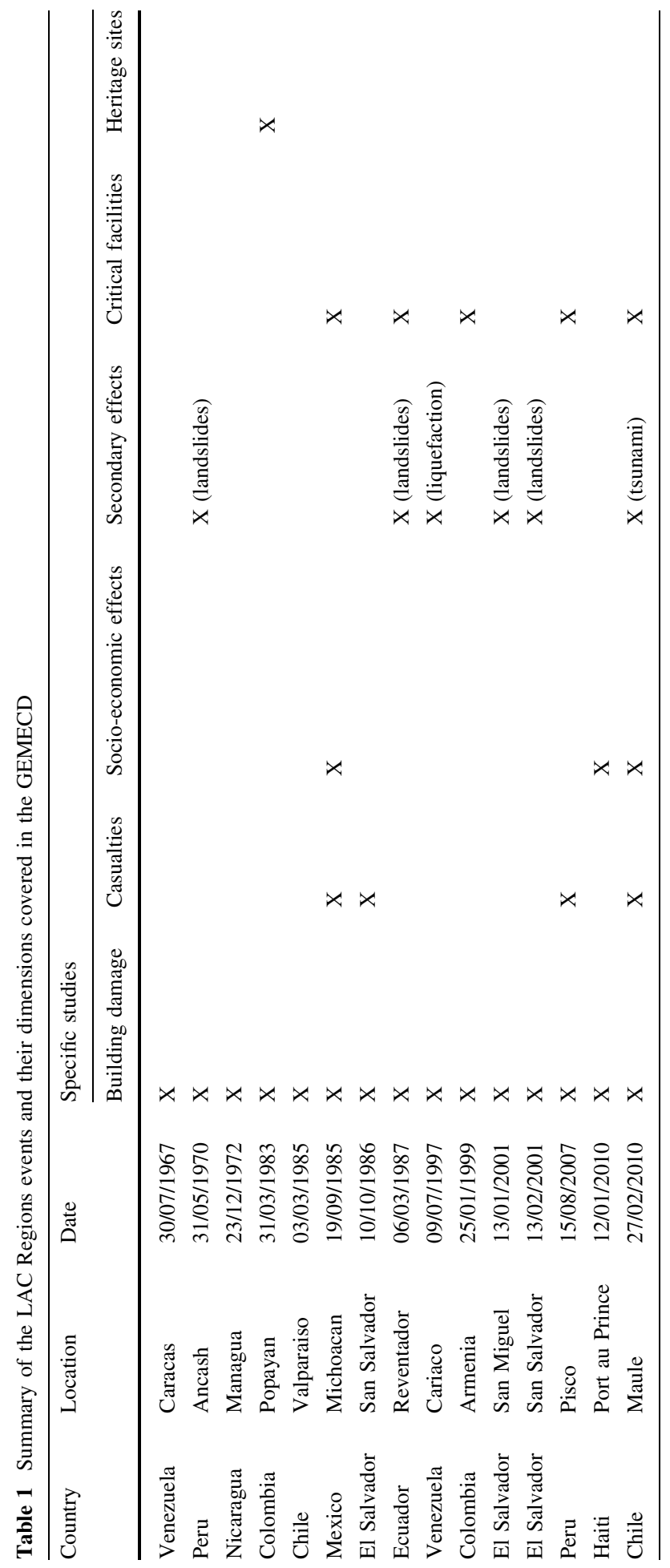


The event has a reported magnitude of $\mathrm{M}_{\mathrm{W}} 6.6$, causing more than 270 fatalities and 1500 injuries (Robson et al. 1968; Ferrer and Cluff 1969; Seed et al. 1970; Apostolos and Kim 1991). Thanks to the collaboration provided by the Venezuelan Foundation for Seismological Investigations-FUNVISIS, access to damage distribution maps such as the one shown in Fig. 2 was granted from where damages to the corresponding taxonomy codes were associated and geo-located in the database. Damage information was available for 13 different locations, being 5 of them located outside the metropolitan area of Caracas.

\subsection{Ancash, Peru, 1970}

The mb 7.5 earthquake caused approximately 32,000 fatalities and 140,000 injuries. Additionally, this earthquake had the peculiarity that besides the damages caused in the built environment as a consequence of the ground shaking, the latter also triggered several landslides. This aspect was considered in the secondary effects category. The damage surveys developed by Plafker et al. (1970, 1971) and Cluff (1971) allowed the characterization of damage levels at 20 different locations.

\subsection{Managua, Nicaragua, 1972}

The Managua 1972 earthquake was other event which, despite having occurred more than 45 years ago, was well and completely documented by several experts in the, at that time emerging, earthquake engineering field. For this $\mathrm{M}_{\mathrm{W}} 6.2$ event, the emphasis of the data gathering was made in the dimension of physical damage, mostly making use of damage distribution maps such as the one shown in Fig. 3. Another source of valuable information about this event was the study conducted by Estrada (1973), a primer in the field at its time, in which in a careful and rigorous manner, the damages on buildings were classified into

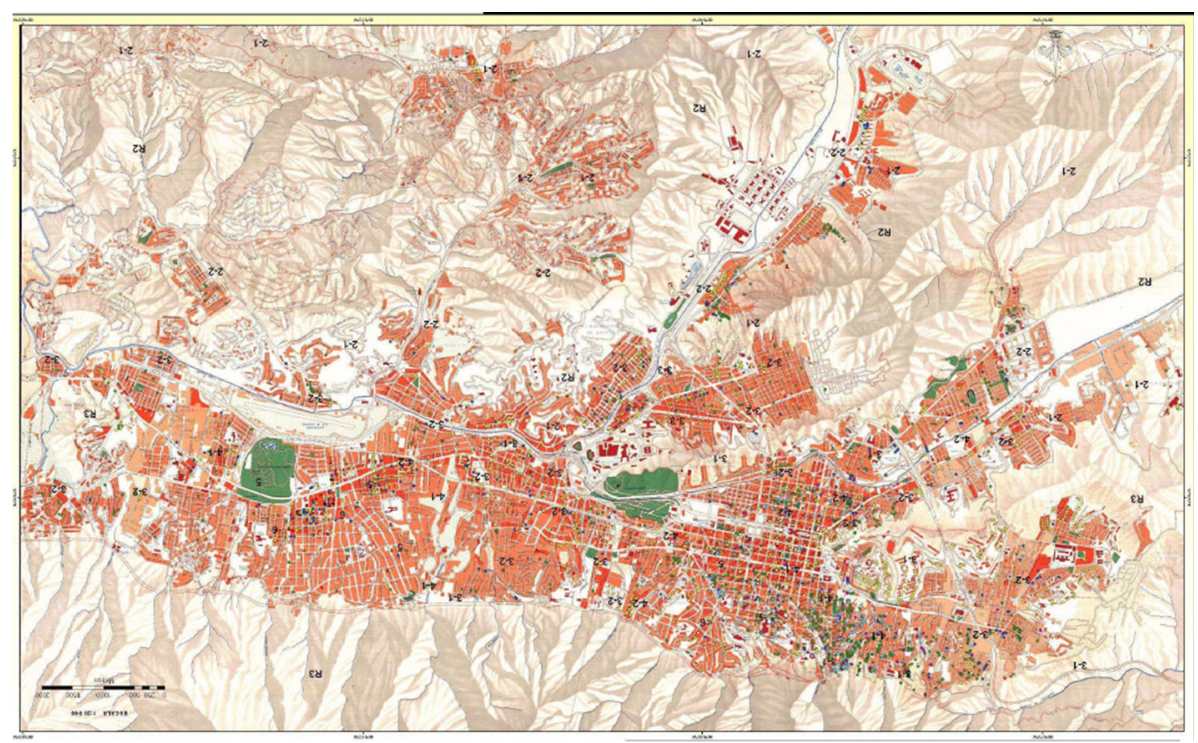

Fig. 2 Geographical distribution of the damage buildings in the 1967 Caracas earthquake. (Reproduced after: FUNVISIS 2004) 


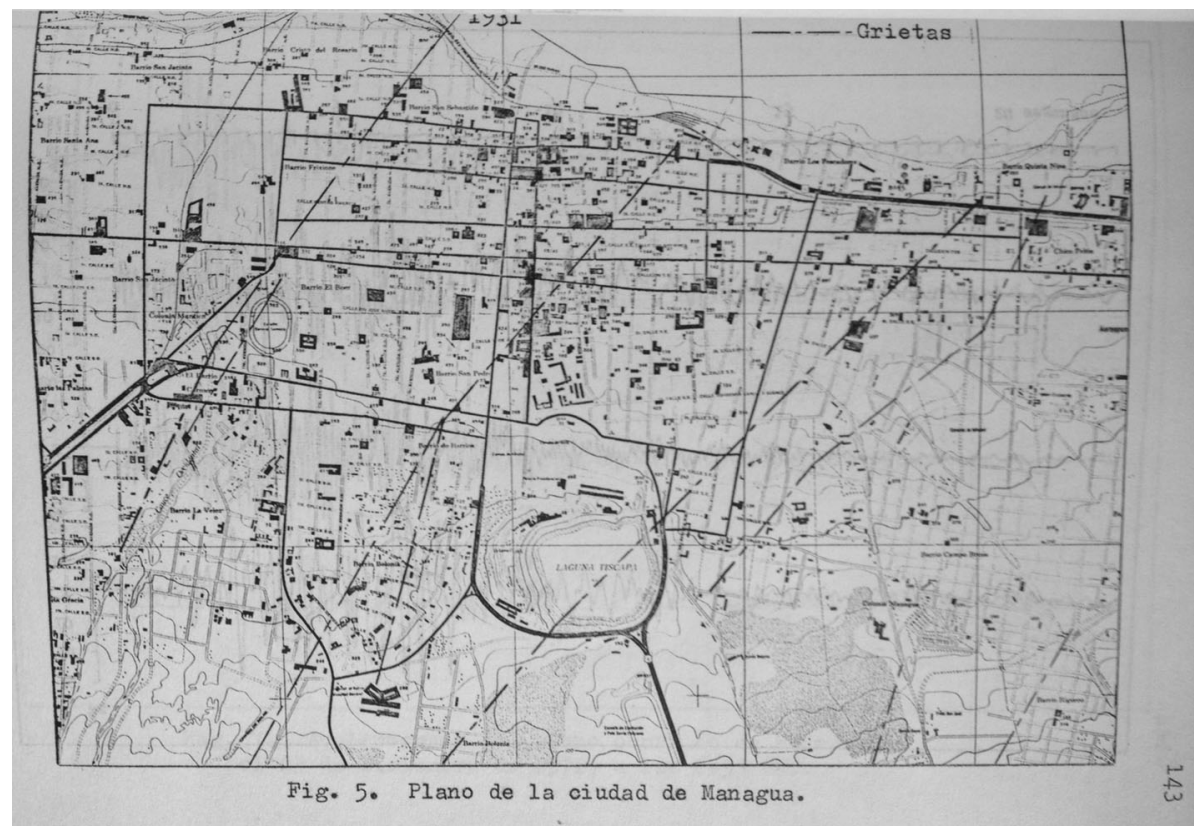

Fig. 3 Damaged buildings in downtown Managua in the 1972 earthquake. (Reproduced after: CEPAL1973)

categories that ranged between small cracks in structural and non-structural components to complete structural collapse.

\subsection{Popayan, Colombia, 1983}

The occurrence of this event represented a change for earthquake engineering in Colombia since it was the ignition spark for the development of local earthquake-resistant building codes and by making its use mandatory in the design and construction of buildings. The first document on this topic was made available to the engineering community 1 year after (AIS 1984), even if before that, local engineers made use of international documents to provide lateral strength in some buildings. The event occurred at a date and time that coincided with the Catholic Easter; being the city of Popayan famous for the ceremonies on that season and having gathered a considerable amount of people, the toll of casualties was large with more than 300 fatalities and 10,000 affected, including around 90 who died as a consequence of the collapse of the roof of the cathedral during a service.

For the database, a compilation of photographs taken by local engineers in the aftermath of the event was made, and additionally, each of them was geo-located, the latter being a highly challenging activity since many of the structures that were heavily damaged by the earthquake do not exist at present time. Damage maps for reinforced concrete buildings in the urban area were also available from where information was geo-coded and later included in the database. 


\subsection{Valparaiso, Chile, 1985}

The information available for this event (Algermissen 1985; Ridell et al. 1987; Wood et al. 1991) allowed the digitalization of damage maps and the geo-location of specific issues for certain buildings in the metropolitan area of the most affected city, Valparaiso. In this case, the information about the characteristics of the buildings was used to associate each class to building classes and codes provided by the GEM Taxonomy.

\subsection{Michoacan, Mexico, 1985}

This earthquake was another particular event from which the Latin American earthquake engineering specialists and community learned several lessons, particularly in the field of dynamic soil response and the importance of developing seismic microzonation studies. Despite having occurred several hundred kilometres away from Mexico City, it was the urban area that resulted most affected due to the soil characteristics and the double resonance effect in buildings with certain characteristics.

In terms of the dimensions to be covered in the database, data associated with most of them could be added in the database. The damage surveys allowed including information about traditional buildings and also on lifelines, mainly for the water and sanitation network of Mexico City. The damage distribution was included for Lázaro Cárdenas (at the vicinity of the epicentre) and also in México City, mostly in the lakebed zones. The socioeconomic consequences included cover the aspects related to the number of people considered as homeless due to the structural damages occurred at their households, but also information about changes in unemployment and economic performance trends due to the disruption caused by the earthquakes was included.

\subsection{San Salvador, El Salvador, 1986}

Despite the large consequences in both physical and human dimensions (more than 10,000 casualties accounting for fatalities and injured) associated with this event, the available information is limited, maybe because of the internal armed conflict that was happening at the same time. In this sense, only the study developed by Bommer et al. (1998), several years later, allows classifying the damaged buildings into categories using a colour scale. Regarding the figure reported for the casualties only an overall association of them to the event was possible to be done.

\subsection{Reventador, Ecuador, 1987}

The ground shaking of this earthquake, which occurred in a rural location of Ecuador, triggered several landslides that inflicted heavy structural damage in a relatively small amount of residential and commercial buildings but also caused breakage of oil pipelines leading to disruption in its distribution and transportation network. Using information on data provided by the Ecuadorian Civil Defence Authorities (DNDCD 1988), damages on residential structures at different locations were included in the database.

Given the high relative importance of the oil industry in Ecuador at the time of the earthquake, and the socio-economic consequences that the disruption on this sector observed at the time, the effort was made in the sense of documenting and including the damages in other component different than buildings. For this, the detailed damage 
information, mostly of those segments located in the vicinity of the Reventador Volcano, available from the study developed by Hall (2000), was used.

\subsection{Cariaco, Venezuela, 1997}

For this earthquake which occurred in north-eastern Venezuela, damage surveys were available for 13 different locations (Schwarz et al. 1998; Rangel 1999). This event had the particularity of causing liquefaction in some locations, and therefore, this aspect was included in the GEMECD as a secondary effect. For these locations on where liquefaction was observed, information about the underlying soil characteristics was available.

For most of the locations inspected, the damage surveys were developed with a block resolution level as shown in Fig. 4 on which the overall damage percentage was reported. These hardcopies were digitalized and the information was included in the GEMECD. One interesting aspect of the information displayed in Fig. 4 is the location of the El Pilar fault which, complemented with the study developed by Audemard (1998) allowed a better description of the geographical damage distributions in the urban area of Cariaco.



Fig. 4 Damage distribution in Cariaco reported at block level. (Reproduced after: González 2002) 


\subsection{Armenia, Colombia, 1999}

This moderate magnitude event affected different cities and rural settlements located in the coffee grow and production region in Colombia. The ground shaking caused the collapse of structures that, in most of the cases, were built with earthen materials and could be classified as non-engineered typologies. Damage data were available for 28 different locations included cities and towns; additionally, and as in the case of Popayan, many photographs (in hardcopy format), taken mostly by local structural engineers, were available. Those were digitalized and geo-located, respectively, in order to be included in the database.

Hospitals, schools, police stations and fire brigade headquarters were heavily damaged as a consequence of the earthquake. In those specific cases, the exact location of each structure was included in the GEMECD together with the pictures that provide a better description and understanding of the damages; for most of the residential and commercial areas of the affected locations, the assessment of damages was performed at block level, as shown in Fig. 5.

\subsection{San Miguel and San Salvador, 2001}

As in the event which also occurred in El Salvador in 1986, the damage data availability for these events is particularly limited. The two events shook El Salvador within a timeframe of 30 days, and the information about the damage is available at country level (MARN 2005). Nevertheless, for the specific landslide occurred in the area known as Las Colinas after the first event the identification of the affected blocks could be performed.

\subsection{Pisco, Peru, 2007}

Being one of the most recent events to be included in the database within the LAC Region, the available information is higher both in number and in detail. The aspects related not only to damage on buildings but also in critical facilities, infrastructure and lifelines were considered, besides the ones that have to do with earthquake casualties. In terms of locations, most of the reports provide information of the observed damages in Pisco, Ica and Chincha with a certain level of detail in the studies developed by Saito (2007), Tavera et al. (2007), Aguero et al. (2008) and Tavera (2008).
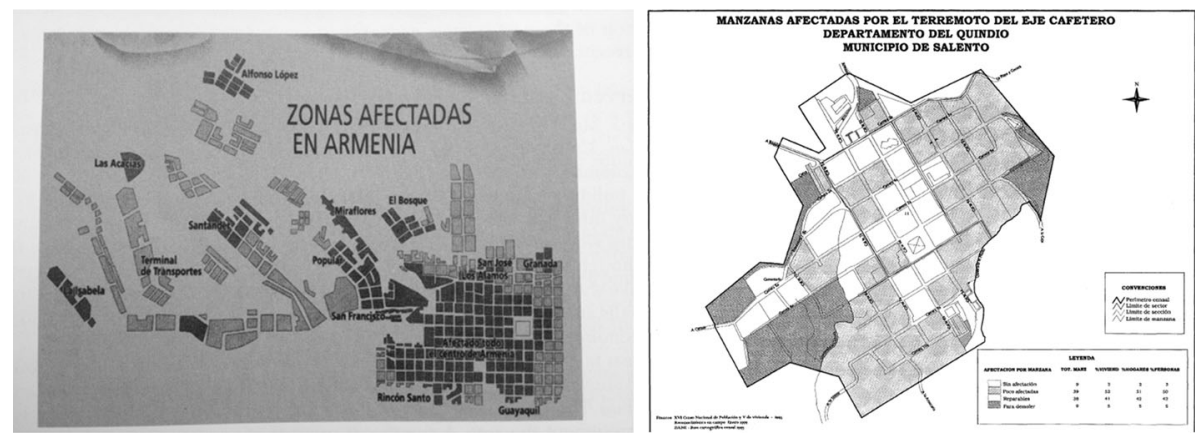

Fig. 5 Damage distribution at block level in Armenia and Salento-Quindío. (Reproduced after: Sarria 1999) 
For damages observed in structures and elements different than buildings and also in non-standard buildings, the study developed by Taucer et al. (2009) was used as a reference, whereas for the inventory of damages observed in the water and sanitation network of Ica, the characteristics and repair rates gathered by ERN-AL (2012) were used as a reference.

\subsection{Port au Prince, Haiti, 2010}

In most reports available for the Haiti 2010 earthquake, it is highlighted that the capital city, Port au Prince, was the most affected area in terms of both physical damages and human casualties. Anyhow, despite the inclusion of many of this information in the GEMECD, using as a reference the work developed by Eberhard et al. (2010), the distribution of damages and casualties in 10 additional locations different than Port au Prince was also developed. As with the other earthquakes, all the building classes used in the available studies were associated with one of the codes compatible with the GEM Taxonomy.

Evidently, the socio-economic aspects of this event were to be considered in the sense that those issues identified as risk drivers are relevant in addressing the sectorial needs and how those were integrated within the national recovery and development plan of the country. This event has highlighted in a clearly manner what is referred to in some cases as saturation of the vulnerability, that is, that with the existing vulnerability levels at the time of the earthquake, an event with lower magnitude would have caused the same, or at least very similar, damages and consequences to those observed in January 2010.

\subsection{Maule, Chile, 2010}

In terms of the dimensions covered, the information gathered for this event and included in the GEMECD accounts for most of them. This is a consequence that the observed damaged occurred not only because of the ground shaking but also by the water run-up of the tsunami triggered by it. Data quality in aspects related to physical damage and casualties was considered of high quality and as reliable, and therefore, most of the information provided by different institutions and organizations was included in the GEMECD. Additionally, damages to critical infrastructure, mostly of bridges located in the national highways together with those reported in buried pipelines, were taken into account and included.

The socio-economic aspects focused on issues related to unemployment and the lack of possibility to return to the houses due to the physical damages. The people affected by the latter were considered as, at least, temporary displaced bearing in mind that some of the areas the suffered the most affection, mainly caused by the tsunami, had recreational and vocational as the main uses.

\section{Conclusions and discussion}

The availability of open and free-to-use global earthquake damages and consequences databases represents a good opportunity to centralize and organize a lot of information that may be useful for experts involved in disaster risk management activities, despite having different specialization fields. An important share of the total number of events included in 
the GEMECD has occurred in the LAC Region, and a big contribution in terms of information related to the database has been made using data with high quality and reliability that allows achieving the overall objective of the initiative.

This project has been a good opportunity not only to put together a large amount of data, around the same topic, but also to standardize, up to a certain level, its representation in order to be even more useful in different activities. Among these activities, the one related to the validation of certain components to be used in analytical loss models (e.g. physical vulnerability). For instance, using the information derived from the effort of validating and updating the shakemaps for particular events together with the reported damages (previously assigned to each building typology), the verification and/or development of vulnerability models can be performed. This last task was to be developed within a separate step and stage of the GEM initiative.

Databases with information about earthquake consequences, available at different resolution levels, complement existing global and national disaster databases and are efforts that are to be encouraged and sponsored in order to make sure not only that information associated with events that occur in the future is properly added but also that other historical events that have not yet been added but for which valuable and reliable information exists are also included.

Acknowledgements The authors are grateful with the following individuals and institutions who made important contributions in the project of including the listed LAC earthquakes in the GEMECD: Emily So, Robin Spence, Antonio Pomonis, Michael Schmitz, Frank Audemard, Leonardo Cano, Hugo Monsalve, Carlos Avelar, Daniela Zuloaga and Claudia P. Villegas; The Venezuelan Foundation for Seismological Investigations (FUNVISIS) and the Colombian Association for Earthquake Engineering (AIS). The authors also acknowledge the suggestions made by the anonymous reviewers who allowed improving the original version of the manuscript.

\section{References}

Aguero C, Tavera H, Fernández E, Huaco P, Talavera C, Arredondo L (2008) Intensidades macrosísmicas en las áreas urbanas de las ciudades de Pisco, Ica y Chincha debidas al sismo del 15 de agosto de 2007. Instituto Geofísico del Perú, Lima

Algermissen ST (1985) Preliminary report of investigations of the Central Chile earthquake of March 3, 1985. U.S. Geological Survey. Open-File Report 87-195. Menlo Park, California

Apostolos SP, Kim J (1991) Study of the propagation and amplification of seismic waves in Caracas valley with reference to the 29 July 1967 earthquake SH waves. Bull Seismol Soc Am 81(6):2214-2233

Asociación Colombiana de Ingeniería Sísmica - AIS (1984) Código Colombiano de Construcciones SismoResistentes. Decreto 1400 de Junio 7 de 1984. Bogotá D.C.

Audemard F (1998) El sismo de Cariaco del 9 de julio de 1997. Estado Sucre, Venezuela: Nucleación y progresión de la ruptura a partir de observaciones geológicas. FUNVISIS, Caracas

Bommer J, Salazar W, Samayoa R (1998) Programa salvadoreño de investigación sobre desarrollo y medio ambiente. Riesgo sísmico en la Región Metropolitana de San Salvador. San Salvador

Cardona OD (2009) La gestión financiera del riesgo de desastre. Instrumentos financieros de retención y transferencia para la Comunidad Andina. PREDECAN, Lima

CEPAL (1973) Informe sobre los daños y repercusiones del terremoto de la Ciudad de Managua en la economía nicaragüense. New York

Cluff LS (1971) Peru earthquake of May 31, 1970. Engineering geology observations. Bull Seismol Soc Am 61(3):511-533

DNDCE - Dirección Nacional de Defensa Civil del Ecuador (1988) Ecuador, terremoto del 5 de marzo de 1987. Quito

Eberhard MO, Baldridge S, Marshall J, Mooney W, Rix GJ (2010) The Mw7.0 Haiti earthquake of January 12, 2010. USGS/EERI Advance Reconnaissance Team report: U.S. Geological Survey Open-File Report 2010-1048 
ERN and Ingeniar Ltda (2014) CAPRA Team RC+. Computer program for fully probabilistic multi-hazard risk assessments. Mexico City

ERN-AL - Evaluación de Riesgos Naturales América Latina (2012) Asistencia técnica para el diseño de una estrategia de protección financiera de riesgo, instrumento financiero específico y una recomendación de políticas para los sistemas urbanos de acueducto y alcantarillado en Perú. Bogotá D.C.

Estrada G (1973) Managua antisísmica: Su ruina y su reconstrucción. Bogotá D.C.

Ferrer D, Cluff L (1969) Caracas, Venezuela earthquake of July 29, 1967. Soil engineering and engineering geology observations. In: Proceedings of the 4th world conference on eathquake engineering, Santiago

FUNVISIS - Fundación Venezolana de Investigaciones Sismológicas (2004) Proyecto de Microzonificación Sísmica en las Ciudades Caracas y Barquisimeto. Informe Técnico Final. Caracas

García D, Mah RT, Johnson KL, Hearne MH, Marano KD, Lin KW, Wald DJ, Worden CB, So E, Wald D (2012) ShakeMap Atlas 2.0: an improved suite of recent historical earthquake ShakeMaps for global hazard analyses and loss models. In: Proceedings of the 15 th world conference on earthquake engineering, Lisbon, Portugal

González J (2002) Microzonificación Sísmico-Geotécnica con base en análisis dinámico y propagación de ondas: Aplicación a la Región de Cariaco, Estado Sucre. Universidad Central de Venezuela

Hall ML (2000) Los terremotos del Ecuador del 5 de marzo de 1987. Deslizamientos y sus efectos socioeconómicos. Quito

MARN - Ministerio de Medio Ambiente y Recursos Naturales de El Salvador (2005) Caracterización del movimiento del suelo y sus efectos en la infraestructura durante los terremotos del 2001, El Salvador. San Salvador

Pagani M, Monelli D, Weatherill G, Danciu L, Crowley H, Silva V, Henshaw P, Buttler L, Nastasi M, Panzeri L, Simionato M, Vigano D (2014) OpenQuake engine: an open hazard (and risk) software for the global earthquake model. Seismol Res Lett 85(3):692-702

Plafker G, Ericksen G, Fernández J (1970) Preliminary report on the geologic events associated with the May 31, 1970 Peru earthquake. Geology Survey Circular 639. University of Texas at Austin, Texas

Plafker G, Ericksen G, Fernández J (1971) Geological aspects of the May 31, 1970 Peru earthquake. Bull Seismol Soc Am 61(3):543-578

Rangel A (1999) Terremoto de Cariaco, Venezuela. Julio 1997. Chronicles of Disasters No. 6. Panamerican Health Organization, Washington, DC

Ridell R, Wood SL, De la Llera JC (1987) The 1985 Chile earthquake. Structural characteristics and damage statistics for the building inventory in Viña del Mar. University of Illinois, Illinois

Robson GR, Canales L, Esteva L (1968) The Caracas earthquake of 29 July 1967. UNESCO, Paris

Saito T (2007) Quick report of building damages in 2007 Peru earthquake. Building research institute, Tsukuba

Salgado-Gálvez MA (2016) Probabilistic assessment of earthquake losses at different scales considering lost economic production due to premature loss of lives. Ph.D. thesis, Universidad Politécnica de Cataluña, Barcelona

Sarria A (1999) Aspectos generales del sismo del Eje Cafetero del 25 de enero de 1999. FASECOLDA, Bogotá D.C.

Schwarz J, Lang D, Habenberger J, Raschke M, Baumach M, Grosser H, Sobseiak M, Welle M, Bonato MA, Hernández A, Romero G, Schmitz M, Avendaño J (1998) The Cariaco, Venezuela, earthquake of July 9, 1997. Engineering analysis of structural damage. In: Proceedings of the 11th European conference on earthquake engineering. Balkema, Rotterdam

Seed HB, Idriss IM, Dezfulian H (1970) Relationship between soil conditions and building damage in the Caracas earthquake of July 29 1967. University of California at Berkeley, California

So E (2014) Introduction to the GEM earthquake consequences database (GEMECD). Global Earthquake Model Foundation, Pavia

Taucer F, Alarcon J, So E (2009) 2007 August 15 magnitude 7.9 earthquake near the coast of Central Peru: analysis and field mission report. Bull Earthq Eng 7(1):1-70

Tavera H (2008) El terremoto de Pisco (Perú) del 15 de agosto de 2007 (7.9Mw). Instituto Geofísico del Perú, Lima

Tavera H, Bernal I, Salas H (2007) El sismo de Pisco del 15 de agosto, 2007. Departamento de Ica-Perú, Instituto Geofísico del Perú, Lima

Wood SL, Stark R, Greer SA (1991) Collapse of eight-story RC building during 1985 Chile earthquake. J Struct Eng 117(2):600-619 